\title{
ATLA Press Update
}

By Christine Fruin, ATLA

During the past year, the ATLA Press made several enhancements and decisions to improve and grow the open access publishing program. ATLA joined the Library Publishing Coalition as a member to not only support and promote the work of ATLA Press but also to utilize LPC's resources to develop educational tools and other programming to support ATLA's members. ATLA also joined CrossRef, which is a Digital Object Identifier (DOI) registration agency. All ATLA open access content will have DOIs assigned to it, and by registering those DOIs with CrossRef, we will improve discovery of and linking to our open access publications.

The open monograph program grew with the addition of two new board members, Myka Kennedy and James Estes, and the promotion of board member Matthew Collins to editor in chief. The board has worked on developing editorial review policies and procedures as well as developing a workflow for review of book proposals and editing of manuscripts within the Open Monograph Publishing system. Future plans for the monograph program include refining the scope of works that will be considered for publication and developing a marketing plan to increase awareness by readers and potential authors.

Theological Librarianship underwent a major publishing platform upgrade with the move to OJS 3 . The journal published two issues during the past year, including a special focus on open access for the October 2017 issue. The journal also revised its author agreement to clarify the rights retained by authors in their individual articles.

Two other ATLA publications made plans to migrate to open access beginning in 2019. Theology Cataloging Bulletin (TCB) and the Summary of Conference Proceedings will be open access and published through OJS, the same publishing platform used by Theological Librarianship. Additionally, $T C B$ will be shifting to a new quarterly publication schedule to allow for a complete volume to fall within a calendar year. Finally, ATLA will begin publishing an annual yearbook in 2019, which will include many of the reports that historically have been part of the annual Proceedings. 
Looking ahead, ATLA is piloting a new journal hosting service with the Wabash Center, who will be publishing a new journal in 2020 through our OJS site http://serials.atla.com. We will also continue to develop webinars, workshops, and other resources related to editorial best practices and library publishing to support the work of our members. 